\title{
Normative Power ASEAN? Globalisation of Asian Values and Its Limits
}

\author{
Ksenia Efremova, MGIMO University, Moscow, Russia
}

Correspondence: efremova@mgimo.ru

\begin{abstract}
The idea of normative power Europe, pioneered by lan J. Manners, is usually applied to the European Union's foreign policy. It states that the EU promotes one's norms and values among adjacent states, determining what is "normal" in international relations. This paper, along with the burgeoning literature that looks for normative power beyond Europe, argues that the Association of Southeast Asian Nations (ASEAN) is another regional grouping that attempts to disseminate its norms and values worldwide, thus transforming itself into a nascent "normative power." Structure-wise, this paper proceeds as follows. First, I will briefly overview the concept of Ian Manner's normative power and its applicability to Europe and Asia. Second, I will determine the Asian values that may be the basis for ASEAN's normative stance in the world. My comparison of ASEAN and the EU's values are structured along with several topical issues: the role of a state in people's quotidian life and the question of human rights promotion. I exemplify the latter with the Myanmar crisis that evoked harsh criticism of the international community. I conclude that the transformation of ASEAN into a "normative power" is rather dubious since there are limits in promoting the Asian norms and values. In ASEAN, there is a group of developing countries that reject Western universalism and struggle to find their own way in world politics.
\end{abstract}

\section{KEYWORDS}

ASEAN, Asian values, normative power, human rights 


\section{Introduction}

Values form the foundation of humanity; but are there universal human values? It may be argued that liberal values (which originated in Europe and widely distributed all around the world) qualify for universal recognition; yet, there still remains the possibility for some alternative sets of values (which might differ greatly from the acknowledged liberal mainstream) to coexist. According to B. Buzan, "one could imagine, for example, an interstate society that is solidarist in the sense of being based on a high degree of ideological uniformity, but where the shared values are nationalist rather than liberal."1 This is precisely the case of Southeast Asia, which has produced the conceptual normative scheme known as "Asian values," which was much criticized and debated in the 1990s.

The bulk of academic literature devoted to this topic ${ }^{2}$ assumes implicitly that "Asian values" represent a kind of intellectual and political challenge to the liberal worldview, yet this is not enough for Southeast Asian countries to take the lead as a global norms provider. A rare exception is a pioneer article by He Jiajie, ${ }^{3}$ where she argues that the Association of Southeast Asian Nations (ASEAN), along with the European Union (EU), may become another world gravity centre in terms of norms and values. As He rightfully suggests, ASEAN can be regarded an emerging "normative power" due to its normative impact on international relations, which somehow corresponds to that of the EU. There is a great difference, however, in the nature of their impact: "The EU's normative power has been considered as the agent of 'Europeanization beyond the EU' [...] and it attempts to influence the domestic politics of its normative targets in the EU's own image. By contrast, ASEAN's normative role is featured as a dialogue-driven process and stresses the importance of negotiation and renegotiation."4

Departing from He's argument that ASEAN should be considered a "normative power," which promotes its own set of values distinct from (and sometimes contradictory to) those of the European tradition, I discuss their nature and international impact. Particularly, I aim to identify ideological concepts that make the core of "Asian values," and to assess critically the possibility of their globalisation (i.e., their spread around the world as an alternative to Western liberal values). Thus, I argue that ASEAN promotes its own set of values worldwide as a part of a broader project to gain more international weight. My arguments are structured as follows: first, I analyse the values that ASEAN promotes and discuss the organization's role as a potential "normative power" (in comparison to the EU). Then, I provide some explanations of how and why ASEAN has become an alternative source of values for developing countries and what the limitations of this self-imposed role are. Further on, I offer some brief remarks on the issue of human rights. In conclusion, the prospects for and obstacles to transforming ASEAN into a genuine "normative power" (including Western criticism) are summarised.

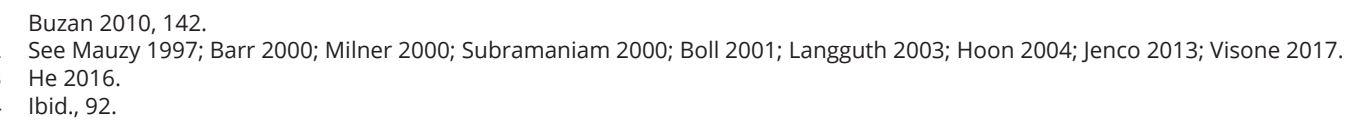




\section{Norms Definition: "Asian Values"}

Much has been written on "normative power Europe" since I.J. Manners introduced the term in his seminal work' published more than 15 years ago. The notion of "normative power" originally referred to the European Union and its changing role in world politics. Manners argues that "the power of ideas and norms," which implies the "ability to shape conceptions of 'normal' in international relations," matters no less than "the power of empirical force." ${ }^{2}$ However, to define certain norms as a normative basis for one's international behaviour is not enough to become a normative power. For that, these norms have to be "diffused" and recognised by other states.

The notion of "normative power," originally applied by I. Manners to the EU, refers to the ability of a state or a group of states to share certain norms and values with other nations and to shape their conceptions of what is "normal" in international relations. ${ }^{3}$ The very idea of Europe as a global norms provider can be traced to colonial times, when the historical mission of Europeans to "civilise" indigenous peoples of Asia, Africa, America, and Australia was considered by many as something natural and unquestioned. The concept of "the White Man's burden," hailed by Nobel laureate Sir R. Kipling, was employed to justify European imperialism and colonial conquests. Portuguese, Spanish, Dutch, British, French, Belgian, Italian, and German colonisers brought with them their religion and customs, which were declared superior to aboriginal traditions. Thus, Western norms and values were (mostly forcefully) introduced to non-Western cultures and ultimately interiorised by local elites.

Decolonisation opened a new chapter in the world history by giving once exploited peoples an equal status with their former masters. It resulted in the rapid growth of postcolonial studies that busted the myth of European superiority. However, the idea of Europe as a cultural and political world centre survived these perturbations, transforming itself into a politically correct form of global normative leadership. Discussing the EU as a normative power, I. Manners distinguishes several core norms that are found in the EU's basic documents, namely: liberty, democracy, respect for human rights and fundamental freedoms, and the rule of law. These norms "clearly have a historical context to them," traditions. Yet, these particular European norms were proclaimed to be universal and fit for all humankind.

The worldwide applicability of European norms and values was challenged by many non-Western intellectuals including a sizable cohort of Southeast Asian politicians and statesmen. The most prominent among them were Lee Kuan Yew (the first prime minister of Singapore) and M. Mohamad (the longest-serving prime minister of Malaysia), who introduced an alternative concept of "Asian values." The concept gained prominence in the late 1980s - early 1990s, when ASEAN witnessed booming economic growth, and was commonly regarded as a regional answer to the spread

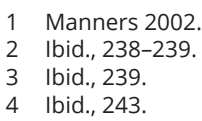


of liberal democratic values, which was perceived by regional elites as "the cultural imperialism of the West." ${ }^{\prime 1}$

It is worth noting that Asian resistance to Western ideological domination originated from those non-communist countries, which declared themselves (and were commonly considered) "democratic," compared to the "undemocratic" communist regimes of China, Vietnam, Laos, and (then) Cambodia. However, their understanding of democracy diverged greatly from the classic European or American model based on the primacy of liberal values. Contrary to Western patterns, Southeast Asian intellectuals deconstructed the very concept of liberal democracy into "liberal" and "democracy," thus making an "illiberal democracy" possible. As F. Zakaria observed,

... it appears that many countries are settling into a form of government that mixes a substantial degree of democracy with a substantial degree of illiberalism. Just as nations across the world have become comfortable with many variations of capitalism, they could well adopt and sustain varied forms of democracy. Western liberal democracy might prove to be not the final destination on the democratic road, but just one of many possible exits. ${ }^{2}$

Some Asian thinkers went even further to proclaim the universality of their own "illiberal values." Thus, "consensus, harmony, unity and community," which form the essence of Asian culture and identity, were proposed as an alternative to Western liberalism. ${ }^{3}$ These views were summarised and codified in the Bangkok Declaration (1993), which acknowledged human rights to be "universal in nature," yet stipulated "the significance of national and regional particularities and various historical, cultural and religious backgrounds." The declaration also stated that "the promotion of human rights should be encouraged by cooperation and consensus, and not through confrontation and the imposition of incompatible values." 4 This passage clearly demonstrates that liberal values were considered "incompatible" by some Asian leaders with their strategies of national development. Therefore, they were replaced by the so-called "Asian values" mentioned above.

What are these Asian values? They are a set of norms, values and attitudes that are derived from the basic thesis of cultural relativism. At the core of Asian values lies an assertion of the cultural particularity of Southeast Asia that makes political liberalisation in the region unnecessary and unwanted. What is upheld instead is statism, or the predominant role of the state over society. The state is seen as a paternalistic, caring and regulating political force, strong and stable, which provides and protects the rights of its citizens. Society is hierarchical, where those who occupy the higher positions possess more rights and, respectively, more responsibilities than those who are underneath. As Barr puts it,

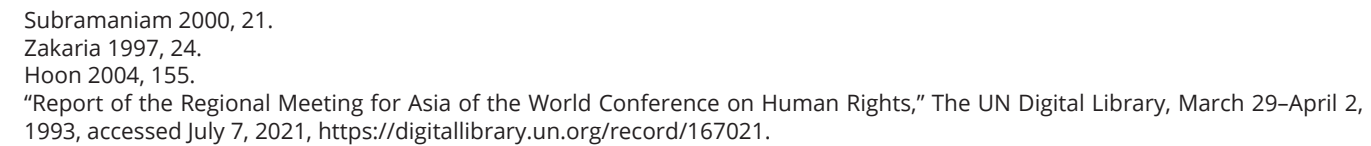


Cultural perspectives originating in the region therefore stem from and tend to lead to a web-like relational or communitarian view of society where everyone knows his or her place in a social hierarchy. This world-view is usually juxtaposed to 'western' liberal and atomistic views of society that emphasise the autonomy of persons. ${ }^{1}$

Asian society is modelled after the traditional family, where the relationship between rulers and subjects is likened to that between fathers and sons. Its main pillars are social order, political stability, collective social norms, communal peace, economic prosperity, consensus building, trust in political leaders, and good governance. It is assumed that

... the moral and ethical bases of a society are rooted in its culture and that Asian and western societies differ fundamentally in their understandings of morality and ethics. In particular, morality and ethics in Asian societies are based on familism and duty as much as rights. In Asian societies one of the roles of the state is to establish those moral and ethical standards. The state has a clear role in determining the moral and ethical criteria on which its society is based, and presumably also in enforcing those criteria. ${ }^{2}$

The following Table compares the fundamental principles of "Asian" and "European" (i.e., Western liberal) societies taken as ideal types, and their respective values.

Table

\section{ASIAN AND EUROPEAN VALUES АЗИАТСКИЕ И ЕВРОПЕЙСКИЕ ЦЕННОСТИ}

\begin{tabular}{cc}
\hline "Asian values" & "European values" \\
\hline Collectivism & Individualism \\
\hline Social hierarchy & Equality and non-discrimination \\
\hline Contextual rights and duties & Universal rights and freedoms \\
\hline Statism & Liberalism \\
\hline Paternalism & Laissez-faire \\
\hline State-imposed social order & Self-organised civil society \\
\hline Morality and ethics & The rule of law \\
\hline
\end{tabular}

Source: compiled by the author.

The Table demonstrates that the concept of Asian values, initially developed by Southeast Asian political philosophers and practitioners, challenges the very foundations of Western liberal society. This intellectual challenge became possible due to the "decolonisation of the mind" (a term popularised by the Kenian writer N. wa Thiong'o in the 1980s), which regional elites have undergone since independence. 
ASEAN appeared in the new system of moral coordinates - one that is no longer centred on Europe - as an alternative source of norms and values for developing countries (most of them being former European colonies), "which are preoccupied with their own historical memories and cultural sensitivity that are very different from those of the EU."1 Thus, Europe was "put in its place" as just one of the world's regions, not necessarily the leading one. This (Southeast) Asian messianism allowed ASEAN to position itself as another normative power, which stands alongside the EU.

However, the logic of cultural relativism demonstrated by Southeast Asian politicians was rejected by many liberal scholars and human rights activists, ${ }^{2}$ who added their voices to the Asian values debate. They argued that Western liberal democracy successfully transcended cultural boundaries, citing Japan, Taiwan, and South Korea as proof. Moreover, some analysts believe that the 1997 Asian financial crisis brought an end to the ambitious Southeast Asian attempt to formulate an ideological alternative to the globalisation of Western norms and values. To them, the inability of "illiberal" Southeast Asian governments to sustain high growth rates meant that Asian values, which proclaimed order and economic prosperity as a part of the social contract, were "thoroughly discredited internationally." It seemed for a moment that the Asian values discourse had become outdated and lost its appeal.

Yet, the idea of common norms and values authentic to Southeast Asian nations as opposed to the "universal" liberal norms and values - persisted in the minds of regional elites. In November 2012, ASEAN leaders adopted the ASEAN Human Rights Declaration, which inherited the ideas formulated in Bangkok 20 years ago. It stated, in particular, that "the enjoinment of human rights and fundamental freedoms must be balanced with the performance of corresponding duties." ${ }^{4}$ This passage raised concerns of many observers, including the UN human rights agency, which pointed out that its wording "does not reflect international human rights law." ${ }^{5}$ Nevertheless, the document was not amended. Its adoption without amendments demonstrates that Asian values are still to be considered an important part of the regional political discourse.

\section{Norms Diffusion: The "ASEAN Way"}

The Asian values debate is usually concentrated on state-society relations. In particular, proponents and opponents of cultural relativism discuss the issue of the liberal democracy and its applicability to non-Western societies. ${ }^{6}$ This discussion focuses on the dilemma of whether ASEAN has developed a unique set of values as an alternative to the Western liberal tradition, or whether there are no "Asian values" as such, but just an attempt of illiberal (and thus undemocratic) Southeast Asian regimes to stay in power for good. As I tried to demonstrate above, there is certainly strong

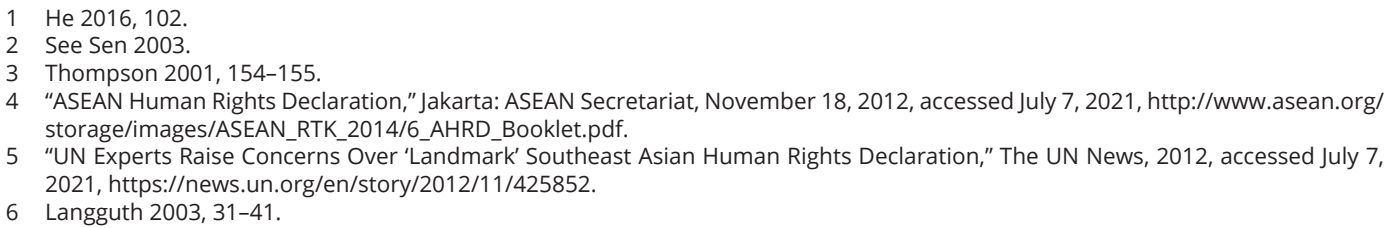

5 "UN Experts Raise Concerns Over 'Landmark' Southeast Asian Human Rights Declaration," The UN News, 2012, accessed July 7, 2021, https://news.un.org/en/story/2012/11/425852.

6 Langguth 2003, 31-41. 
evidence to support the former point of view. European universalism is deeply rooted in tragic experiences of the colonial past, when voices of aboriginal peoples were ruthlessly subdued. What we witness today is the natural revivalism of once culturally subjugated nations, which struggle to formulate an indigenous response to continuing Western ideological pressure. ${ }^{1}$

This is a question of norms production. However, to become a normative power, it is not enough to produce specific norms and values: it also means to employ certain policy instruments to spread and ensure the acceptance of these norms both domestically and internationally. ${ }^{2}$ In other words, it is a question of norms diffusion. My paper further addresses the issue of the "alternative normality" in international relations, which is promoted by ASEAN. I argue, in particular, that its implementation through multilateral mechanisms of regional and interregional cooperation provides a unique chance for ASEAN to be followed by other developing states of the global South. Moreover, these diplomatic tools sustain the ASEAN's image as alternative provider of international norms to the $\mathrm{EU}$, and facilitate its participation in the processes of global governance.

To begin with, let me trace the origin of the "alternative normality" in international relations, which is pushed (and somehow privatised) by Southeast Asian countries. It can be dated back to 1954, when Panchsheel (the Five Principles of Peaceful CoExistence) were proclaimed as the guiding principles for China-India and ChinaMyanmar relations, as well as for their relations with all other countries of the world. These principles included: (1) mutual respect for each other's territorial integrity and sovereignty; (2) mutual non-aggression; (3) mutual non-interference; (4) equality and mutual benefit; and (5) peaceful co-existence. ${ }^{3}$ Thus, a formal diplomatic foundation was laid for a peaceful co-existence of communist and non-communist countries something unthinkable in the historical context of that time, when the Cold War was unfolding between the United States and the USSR.

In 1955, Panchsheel were incorporated into the Ten Principles of International Peace and Cooperation set out in the Final Communiqué of the Asian-African conference of Bandung, which was signed by 29 Afro-Asian countries, among them the future founders of ASEAN - Indonesia, Thailand, and the Philippines, as well as Myanmar, Laos, Cambodia, North and South Vietnam. The relevance of Panchsheel was further emphasised when their tenets were integrated into the Declaration on Peaceful and Neighbourly Relations among States (A/RES/12/1236) co-sponsored by India, Yugoslavia and Sweden, which was unanimously adopted by the United Nations General Assembly on December 14, 1957. In 1961, the Conference of NonAligned Nations in Belgrade (attended by three Southeast Asian nations - Indonesia, Myanmar, and Cambodia) accepted Panchsheel as the principled core of the NonAligned Movement's ideology. ${ }^{4}$

Panchsheel laid down the foundation for the basic principles of intra-ASEAN relations proclaimed in the Treaty of Amity and Cooperation in Southeast Asia, which

3 "Panchsheel," Ministry of External Affairs, Government of India, 2004, accessed July 7, 2021, http://www.mea.gov.in/Uploads/ PublicationDocs/191_panchsheel.pdf.

4 "Panchsheel." 
was adopted on the $1^{\text {st }}$ ASEAN Summit, held on Bali, Indonesia in 1976. They were: (1) mutual respect for the independence, sovereignty, equality, territorial integrity and national identity of all nations; (2) the right of every state to lead its national existence free from external interference, subversion or coercion; (3) non-interference in the internal affairs of one another; (4) settlement of differences or disputes by peaceful means; (5) renunciation of the threat or use of force; and (6) effective cooperation among themselves. ${ }^{1}$ It is easy to notice that the Treaty's provisions reiterated the norms of international interaction originated in Panchsheel.

These principles make the core for what is known as "the ASEAN Way," a unique set of diplomatic practices based on informal consultations and consensus decisionmaking. Its fundamental tenets, such as musyawarah (consultation) and mufakat (consensus-building), are deeply rooted in Malay cultural traditions that have eventually developed within the region. Decision-making in the ASEAN way means that, "if a consensus cannot be reached on a contentious issue, the ASEAN member states agree to disagree and go their separate ways, with ASEAN assuming no official position on the issue [...] When intra-ASEAN issues cannot be resolved, they can be put aside so that they do not interfere with cooperation on other matters." ${ }^{2}$ This passage clearly indicated that there is a marked difference in decision-making procedures compared to negotiation practices employed in the EU.

Another point of divergence between ASEAN and the EU is their attitudes towards the logic of maintaining regional peace and stability. The foreign policy of the united Europe derives from the democratic peace theory, which stipulates that "democracies do not fight each other." To guarantee a peaceful international environment, the EU promotes democratic values within its neighbourhood, supporting (sometimes insistently) democratic trends there. The European Neighbourhood Policy launched in 2003 and reviewed in 2011 "is based on the values of democracy, rule of law and respect of human rights." ${ }^{3}$ Unlike the EU, ASEAN does not insist on political transformation of future members towards democracy (as was the case with Brunei, Vietnam, Laos, Myanmar, and Cambodia). However, it conditioned their membership on acceding to the Treaty of Amity and Cooperation in Southeast Asia that contains the core norms and principles to which ASEAN adheres.

This difference can be explained theoretically by contrasting the nature of ASEAN and the EU. In a recent study, He makes an insightful comparison of ASEAN and EU's policies as normative powers. She argues that the EU and ASEAN employ different policy instruments to spread their norms and ensure their acceptance by other countries. As a "collective great power," the EU "is a hegemonic actor that tends to socialize its normative targets by imposing conditionality" (e.g. democracy, human rights, etc.), while "ASEAN's normative role is more accommodative and inclusive" because it is composed of "relatively weak and developing states." ${ }^{4}$ Unlike the EU, ASEAN's institutional practices lack enforcement measures that attempt to influence

1 "Treaty of Amity and Cooperation in Southeast Asia, 1976," February 1976, accessed August 3, 2021, http://asean.org/treatyamity-cooperation-southeast-asia-indonesia-24-february-1976.

2 Koga 2010, 81.

3 "European Neighbourhood Policy," 2016, accessed July 7, 2021, https://ec.europa.eu/neighbourhood-enlargement/ neighbourhood/overview_en.

4 He 2016, 96-99. 
and reshape domestic politics of target countries. The policy instruments employed by ASEAN to spread its norms worldwide include cumulative dialogue and social (re) negotiations through regional institutions, which are accommodative in nature. ${ }^{1}$

It follows that ASEAN regionalism (and inter-regionalism) is not "intrusive," but "inclusive." 2 This means that ASEAN does not interfere in the internal affairs of its members and dialogue partners, offering them a culture of mutual respect, compromise and consultations. This culture is aimed at "socializing" other countries by making their regional policies compatible with the "ASEAN way." To achieve this goal, ASEAN countries urge their partners to accede to the Treaty of Amity and Cooperation in Southeast Asia (1976), which is the basic document that sets out the principles of the intra-regional code of conduct. However, major dialogue partners of ASEAN have long been reluctant to become a signatory to the Treaty. For example, China and India joined the Treaty in 2003, Russia, Japan and South Korea in 2004, Australia and New Zealand in 2005, the United States in 2009, Canada in 2010, and the EU only in 2012.

ASEAN dialogue partnerships can be divided into two broad categories: (1) extraregional powers - China, India, Japan, Australia, the United States, Russia, etc.; and (2) regional organisations and groupings composed of European, Latin American, Asian and African states. Their relations form two distinct types of interaction: "subject-object" and "subject-subject." The former types of interaction are asymmetric due to the uneven power distribution between the parties, while the latter are equal (though both are mutually beneficial). Historically, "subject-object" relations dominated in the structure of ASEAN international cooperation patterns. It was not until the 1990s, when "subject-subject" relations appeared on the ASEAN agenda. At present, however, it is relations of the second type that constitute the bulk of ASEAN interregional arrangements.

"Subject-object" relations are characterised by power disparity, which requires special cooperation patterns. Having long been considered an "object" in geopolitical games of its mighty partners, ASEAN demonstrated its outstanding diplomatic skills by offering them an asymmetric model of interaction, where it plays a central role by forming and transforming the international milieu (the "driver's seat" phenomenon). This concept "helps create strategic space for a grouping of relatively weak countries to enjoy a measure of latitude they would otherwise not be able to move on their own."3 The ASEAN centrality, approved and supported by extra-regional actors, helps ensure that no one of them will prevail in the region at the expense of other parties. Thus, ASEAN guarantees equidistance and non-alignment to external powers, facilitating peaceful dialogue among them.

A classic example of "subject-object" relations is the system of ASEAN dialogue partnerships, which dates back to the mid-1970s and is based on the mechanism of consultations with external powers in the bilateral format of ASEAN+1. These consultations are usually held after the annual ASEAN Foreign Ministers' Meeting, where the latter develop a common stance on issues that ought to be discussed with their partners. These consultations are thus dubbed "Post-Ministerial Conferences" 
(PMC). The PMC practice eventually evolved into ASEAN+1, ASEAN+3 (China, Japan, South Korea), and ASEAN+CER (Australia, New Zealand) summits, which constitute the base for ASEAN partnership relations at present. The principle of ASEAN centrality, which makes these dialogue partnerships possible, implies that extra-regional powers strive to accommodate ASEAN-promoted norms and values. Even in those cases when an explicit conflict of interests occurs, ASEAN still attempts to work out a code of conduct that prevents open confrontation between parties.

"Subject-subject" relations allow ASEAN to establish equitable cooperation with other regional groupings. Here it acts as an international organization, which spreads its norms and values abroad by extending the ASEAN way principles onto its partner institutions. Instead of "formal negotiations with identifiable and enforceable benchmarks, and more generally within a framework that stresses the rule of law," ASEAN offers a paradigm of informal consultations with non-binding obligations reached by consensus. Set against the Western liberal approach, the ASEAN way "presents an increasingly distinctive and influential option for other states, especially those in the global South."1 By discussing issues of interregional and global importance, ASEAN attempts to find a consensus solution that benefits all parties concerned. This kind of cooperation strengthens ASEAN international positions, giving it a chance to participate in the process of global governance.

"Subject-subject" relations can be illustrated by ASEAN's interaction with other regional groupings: the European Union (EU), the Economic Cooperation Organization (ECO), the Gulf Cooperation Council (GCO), the Southern African Development Community (SADC), the Shanghai Cooperation Organisation (SCO), the South Asian Association for Regional Cooperation (SAARC), etc. Other examples of ASEAN's interregional cooperation include the Asia-Europe Meeting (ASEM), the Forum for East Asia-Latin America Cooperation (FEALAC), and the Asia Cooperation Dialogue (ACD). These particular dialogue platforms are especially interesting because they were established at ASEAN's initiative and therefore their founding documents bear the stamp of ASEAN ideology.

Thus, the Final Chair Statement of the $1^{\text {st }}$ ASEM summit held in Bangkok in 1996 requires that "the dialogue among the participating countries should be conducted on the basis of mutual respect, equality, promotion of fundamental rights and, in accordance with the rules of international law and obligations, non-intervention, whether direct or indirect, in each other's internal affairs." ${ }^{2}$ The same fundamental principles - "respect for each other's sovereignty and territorial integrity; noninterference in each other's internal affairs; equality, mutual benefit and the common goal of development; respect for each other's unique cultures and social values; and decision-making by consensus" - were included in the framework document signed by FEALAC foreign ministers at the inaugural meeting held in Santiago, Chile in 2001. ${ }^{3}$ A year later, they were reiterated in Cha-Am, Thailand, where foreign ministers from

2 "New Comprehensive Asia-Europe Partnership for Greater Growth, 1st ASEM Summit (ASEM1)," Asia-Europe Meeting, ASEM Infoboard, March 1-2, 1996, accessed August 2, 2021, https://cdn.aseminfoboard.org/documents/1996_-_ASEM1_-_Chair_ Statement_Svhj1Gx.pdf.

3 "Framework for a Forum for Dialogue and Cooperation between East Asia and Latin America," March 30, 2001, accessed July 7, 2021, http://www.fealac.org/File_download.jsp?Type=OFFICE\&AttachFileldx=50. 
18 Asian countries met together to establish the Asia Cooperation Dialogue.

To sum up, it seems obvious that ASEAN not only proclaims its own norms and values distinct from those of the $\mathrm{EU}$, but has also established an effective mechanism of globalising its normative practices through the system of dialogue partnerships and interregional arrangements. But when it comes to international recognition of these norms, ASEAN is on shaky ground. The very idea of illiberal values is exposed to the fierce criticism of those scholars and politicians who refuse to admit the thesis of cultural relativism that implies the existence of alternative, non-mainstream worldviews. To them, the ASEAN leaders who reject the universal nature of liberal values are mistaken at best, or misleading at worst.

\section{Norms Controversy: The Human Rights Issue}

The main point of collision between the proponents and opponents of Asian values is the issue of human rights. The discussion centres on the argument of whether or not human rights violations justify humanitarian intervention. The ASEAN governments reject any interference in the internal affairs of other states, including for humanitarian reasons, while their Western partners insist on promoting the notion of upholding human rights.

One of the most telling cases here is Myanmar, which has been in the focus of international attention for more than 30 years due to its poor human rights record. ASEAN used to defend Myanmar from international ostracism, which was caused by its domestic policies. What is interesting here is the positive stance that ASEAN as a group has taken towards Myanmar, an ASEAN member country, despite fierce criticism from the UN Security Council, the Office of the United Nations High Commissioner for Human Rights, Human Rights Watch and other human rights agencies, as well as from their own citizens. It is worth noting that ASEAN's common desire to prevent extra-regional powers from intervening in regional affairs prevails over the individual concerns of its member countries. The Myanmar case clearly demonstrates that ASEAN's unity is based on common norms and values, which are shared by all Southeast Asian countries regardless of their political, cultural or religious background - and that they are quite different from the liberal norms and values praised by the West.

For the EU, human rights are fundamental values, which have to be upheld anytime and anywhere. For ASEAN, however, it is regional cohesion that takes the primary position in the hierarchy of values; ASEAN prefers to overlook Myanmar's poor human rights record in order to maintain "regional resilience" (i.e., the ability to collectively sustain peace and stability in the region). It has to be acknowledged, further, that the ASEAN way of dealing with Myanmar proved to be more effective in terms of reaching the ultimate goal - spreading its norms and values to Yangon / Nay Pyi Taw - while the EU apparently failed the task. That can be explained by common Southeast Asian mentality, which the EU underscored.

The Myanmar story is a long story of misunderstanding between the EU (and the West in general) and their Southeast Asian partners, whose understanding of democratic governance is based on a rather different set of norms and values. Whether these values are good or bad is up for debate (though analysts should refrain from any value judgments). What must be stressed, however, is that assigning virtues 
to ASEAN that it never possessed - such as a desire for promoting (liberal) democracy in Southeast Asia - is counterproductive. Take, for example, the commonly accepted vision that ASEAN's efforts in human rights socialization are "widely considered to be a failure."1 This implicitly assumes that ASEAN intends to promote human rights (just as the EU does), while it does not. What ASEAN does promote, however, is "Asian values" and the "ASEAN way" - and this is a story of success rather than one of failure.

\section{Conclusion}

IS ASEAN a normative power? There is some evidence that supports the point of view that it is. But ASEAN also faces a great challenge in attempting to spread its norms and values worldwide - and this is the challenge of cultural relativism, which constitutes the fundamental base of its normative vision. Southeast values are by definition confined to the borders of Southeast Asia. They are non-universal by their nature since "they are conditioned by national and regional particularities and various historical, cultural and religious backgrounds." ${ }^{2}$ Therefore, they could hardly be globalised in the same sense as the EU's (liberal) values, which are widely considered to be universal. When it comes to norms recognition, ASEAN's potential as a norms provider is limited to a group of developing countries that reject Western universalism and struggle to find their own way in world politics. Nevertheless, ASEAN's normative role as an ideological alternative to the EU should not be underestimated and deserves further study. 


\section{СПИСОК ЛИТЕРАТУРЫ / REFERENCES}

Ba, Alice. (Re)Negotiating East and Southeast Asia: Region, Regionalism, and the Association of Southeast Asian Nations. Stanford, CA: Stanford University Press, 2009.

Barr, Michael D. "Lee Kuan Yew and the 'Asian values' debate." Asian Studies Review 24, no. 3 (2000): 309-334. https://doi.org/10.1080/10357820008713278.

Boll, Alfred M. "The Asian Values Debate and its Relevance to International Humanitarian Law." International Review of the Red Cross 83, no. 841 (2001): 45-58. https://doi.org/10.1017/S1560775500106170.

Buzan, Barry. "Reconstructing the PluralistSolidarist Debate". In From International to World Society? 139-160. Cambridge: Cambridge University Press, 2010. https://doi.org/10.1017/CBO9780511616617.008.

Dascal, Marcelo. Colonizing and Decolonizing Minds. Tel Aviv: Tel Aviv University, 2007.

Davies, Mathew. "The Perils of Incoherence: ASEAN, Myanmar and the Avoidable Failures of Human Rights Socialization?" Contemporary Southeast Asia, 34, no. 1 (2012): 1-22.

He, Jiajie. "Normative Power in the EU and ASEAN: why they Diverge." International Studies Review 18, no. 1 (2016): 92-105. https://doi.org/10.1093/isr/viv028.

Hoon, Chang Yau. "Revisiting the Asian Values Argument Used by Asian Political Leaders and its Validity." Indonesian Quarterly 32, no. 2 (2004): 154-174.

Jenco, Leigh. "Revisiting Asian Values." Journal of the History of Ideas 74, no. 2 (2013): 237-258. https://doi. org/10.1353/jhi.2013.0014.

Koga, Kei. "The Normative Power of the 'ASEAN Way': Potentials, Limitations and Implications for East Asian Regionalism." Stanford Journal of East Asian Affairs 10, no. 1: 80-95.

Langguth, Gerd. "Asian Values Revisited." Asia Europe Journal 1, no. 1 (2003): 25-42. https://doi. org/10.1007/s103080200005.
Manners, lan. "Normative Power Europe: A Contradiction in Terms?" Journal of Common Market Studies 40, no. 2 (2002): 235-258. https://doi. org/10.1111/1468-5965.00353.

Mauzy, Diane K. "The Human Rights and 'Asian Values' Debate in Southeast Asia: Trying to Clarify the Key Issues." Pacific Review 10, no. 2 (1997): 210-236. https://doi.org/10.1080/09512749708719218.

Milner, Anthony. "What happened to 'Asian Values'?" In Towards Recovery in Pacific Asia, edited by Segal, G. and Goodman, D., 55-68. London, Routledge, 2000.

Sen, Amartya Kumar. Human Rights and Asian Values. New York: Carnegie Council on Ethics and International Affairs, 2003.

Stubbs, Richard. "The ASEAN Alternative? Ideas, Institutions and the Challenge to 'Global' Governance." Pacific Review 21, no. 4 (2008): 451-468.

Subramaniam, Surain. "The Asian Values Debates: Implications for the Spread of Liberal Democracy." Asian Affairs 27, no. 1 (2000): 19-35.

Tan, See Seng. "Rethinking 'ASEAN Centrality' in the Regional Governance of East Asia." The Singapore Economic Review 62, no. 3 (2017): 721-740. https://doi. org/10.1142/S0217590818400076.

Thiong'o, Ngugi wa. Decolonising the Mind: the Politics of Language in African Literature. Nairobi: East African Education Publisher, 1986.

Thompson, Mark R. "Whatever Happened to 'Asian Values'?" Journal of Democracy 12, no. 4 (2001): 154-165. https://doi.org/10.1353/jod.2001.0083.

Visone, Tommaso. "The 'ASEAN Way'. A Decolonial Path beyond 'Asian Values'?" Perspectives on Federalism 9, no. 1 (2017): E1-E12. https://doi.org/10.1515/pof-20170001.

Zakaria, Fareed. "The Rise of Illiberal Democracy." Foreign Affairs 76, no. 6 (1997): 22-39.

\section{Author}

Ksenia A. Efremova,

PhD (Political Science), Associate Professor, Department of Asian and African Studies, Research Fellow, Centre for Comprehensive Chinese Studies and Regional Projects, MGIMO University,

119454, Moscow, Vernadsky Prospekt, 76.

e-mail: efremova@mgimo.ru

\section{Additional information}

Received: March 10, 2021. Revised: July 27, 2021. Accepted: August 3, 2021.

\section{Acknowledgments}

The author is grateful to organisers and participants of the IPSA RC36 Papers Development Workshop "Empirical Analysis of Political Power" held on May 24, 2019 in Saint Petersburg, Russia, for their valuable comments on an earlier version of this paper.

\section{Disclosure statement}

No potential conflict of interest was reported by the author.

\section{For citation}

Efremova, Ksenia A. "Normative Power ASEAN? Globalisation of Asian Values and Its Limits." Journal of International Analytics 12, no. 2 (2021): 93-106. https://doi.org/10.46272/2587-8476-2021-12-2-93-106 


\title{
Есть ли у АСЕАН нормативная власть? Глобализация азиатских ценностей и ее пределы
}

\begin{abstract}
АННОТАЦИЯ
Концепция «нормативной власти», впервые введенная Яном Дж. Маннерсом, обычно применяется к внешней политике Европейского союза (ЕС). Она описывает способность распространять свои нормы и ценности среди других (чаще - соседних) государств, формируя общепринятое понимание того, что является «нормальным» в международных отношениях. В данной работе, присоединяющейся к набирающей популярность литературе, посвященной поиску феномена нормативной силы за пределами Европы, утверждается, что Ассоциация государств Юго-Восточной Азии (АCЕАН) является еще одной региональной группировкой, которая пытается распространить свои нормы и ценности по всему миру, тем самым превращая себя в источник «нормативной силы». В структурном плане данная

работа построена следующим образом. Во-первых, автор кратко останавливается на концепции нормативной власти Я. Маннерса и ее применимости по отношению к Европе и Азии. Во-вторых, в статье определяются азиатские ценности, которые могут быть основой для нормативной позиции АCEAН в мире. Сравнение ценностей АCEAH и ЕС построено на рассмотрении двух проблем: роли государства в повседневной жизни людей и продвижении прав человека. В качестве примера последнего автор останавливается на кризисе в Мьянме, который вызвал резкую критику со стороны международного сообщества. Делается вывод, что превращение АСЕАН в «нормативную державу» весьма сомнительно, поскольку ее потенциал как поставщика норм ограничен группой развивающихся стран, которые отвергают западный универсализм и пытаются найти свой собственный путь в мировой политике.
\end{abstract}

\section{КЛЮЧЕВЫЕ СЛОВА}

АСЕАН, азиатские ченности, нормативная власть, права человека

\section{Сведения об авторе}

Ксения Александровна Ефремова,

к.полит.н., доцент Кафедры востоковедения, научный сотрудник Центра комплексного китаеведения и региональных проектов, МгИМО Университет, 119454, Москва, Проспект Вернадского, 76.

email: efremova@mgimo.ru

\section{Дополнительная информация}

Поступила в редакцию: 10 марта 2021.

Переработана: 27 июля 2021.

Принята к публикации: 3 августа 2021.

\section{Благодарности}

Я благодарна организаторам и участникам семинара IPSA RC36 Papers Development Workshop "Empirical Analysis of Political Power," состоявшегося 24 мая 2019 года в Санкт-Петербурге, за ценные комментарии к ранней версии этой статьи.

\section{Конфликт интересов}

Автор заявляет об отсутствии потенциального конфликта интересов.

\section{Цитирование}

Ефремова, К.А. Есть ли у АСЕАН нормативная власть? Глобализация азиатских ценностей и ее пределы // Международная аналитика. - 2021. - Том 12 (2). - С. 93-106. https://doi.org/10.46272/2587-8476-2021-12-2-93-106 